\title{
Pentingnya Penyuluhan Hukum "Penyelesaian Sengketa di Luar Pengadilan (Mediasi) dan Pemahaman tentang Pembuatan Sertifikat Tanah di Kecamatan Juhar dan di Desa Sari Nembah, Kabupaten Karo
}

\author{
Maria Kaban \\ Fakultas Hukum, Universitas Sumatera Utara, Medan \\ mariakabans@yahoo.com
}

\begin{abstract}
Abstrak
Kedamaian hidup merupakan idaman dan harapan dari semua orang. Suatu kehidupan yang damai hanya akan tercapai jika di dalam suatu masyarakat tercipta suatu kehidupan yang tertib dan tenteram. Sehingga bisa dikatakan bahwa kedamaian akan dapat tercapai apabila tidak ada terjadi persengketaan di masyarakat, jika dilihat lebih jauh untuk masa sekarang ini, upaya yang ditempuh untuk mencegah terjadinya sengketa dapat dikatakan hampir mustahil. Hal itu disebabkan semakin majunya masyarakat, maka akan semakin banyak kemungkinan terjadinya gesekan diantara masyarakat tersebut. Salah satu sengketa yang sering terjadi di kalangan masyarakat antara lain adalah sengketa tanah. Sengketa tanah yang timbul di desa pada umumnya adalah sengketa kepemilikan tentang tanah yang disebabkan kurangnya pemahaman masyarakat terhadap pendaftaran tanah. Sehubungan dengan hal itu, dibuatlah rumusan masalah yaitu (1) Apakah upaya terbaik yang harus dilakukan oleh tim pengabdian masyarakat serta manfaat yang akan diperoleh mitra mitra (masyarakat Desa Sarinembah dan Kecamatan Juhar, Kabupaten Karo) dalam hal menjadikan mediasi sebagai opsi utama dalam penyelesaian sengketa, khususnya di Desa Sarinembah dan Kecamatan Juhar, Kabupaten Karo?, (2). Apakah upaya terbaik yang harus dilakukan oleh tim pengabdian masyarakat serta manfaat yang akan diperoleh mitra (masyarakat Desa Sarinembah dan Kecamatan Juhar, Kabupaten Karo) dalam hal menanamkan pentingnya pendaftaran tanah bagi warga di Desa Sarinembah dan Kecamatan Juhar, Kabupaten Karo?, (3). Manfaat apa yang dapat diperoleh oleh pemerintah dalam hal ini pihak Kabupaten Karo dengan diadakannya pengabdian oleh pihak akademisi? Kegiatan yang dilakukan dalam pengabdian masyarakat ini adalah dalam bentuk ceramah umum kepada kelompok sasaran yang strategis dan tanya jawab langsung (diskusi) antara penceramah dengan kelompok sasaran serta secara keseluruhan melihat perkembangan pelaksanaan mediasi dan pelaksanaan pendaftaran tanah di desa dan kecamatan yang menjadi mitra. Berdasarkan pengabdian yang dilakukan maka diperolehlah hasil yaitu: (1) Masyarakat menjadi lebih mengerti mengenai alternatif lain dalam penyelesaian sengketa yaitu melalui jalur mediasi yang ternyata lebih menghemat waktu serta melakukan pendaftaran tanah untuk mejamin kepastian hukum kepemilikan atas tanah. (2) Para pemuka masyarakat, agama maupun perangkat Desa Sarinembah dan Kecamatan Juhar menyatakan akan berusaha untuk mengarahkan sengketa perdata yang terjadi di dalam masyarakat Desa Sarinembah dan Kecamatan Juhar penyelesaiannya dilakukan melalui jalur mediasi serta meningkatkan minat masyarakat untuk melaksanakan pendaftaran tanah. (3) Pengabdian masyarakat seperti ini juga turut membantu sosialisasi pemerintah dalam bidang hukum. Setelah dilaksanakannya pengabdian masyarakat ini, diharapkan masyarakat Desa Sarinembah dan Kecamatan Juhar dapat melihat bahwa dalam menyelesaikan sengketa terutama sengketa perdata, tidak harus melalui jalur pengadilan yang cenderung menghabiskan banyak biaya daan waktu serta menyebabkan penumpukan kasus di pengadilan, namu tersedia jalur lain yang lebih hemat biaya dan waktu yaitu melalui penyelesaian sengketa alternatif dan dalam hal pendaftaran tanah agar masyarakat dapat melaksanakan pendaftaran tanahnya untuk menjamin kepastian hukum serta menghindarkan terjadinya sengketa.
\end{abstract}

Kata kunci : sengketa, pengabdian, mediasi, pendaftaran tanah

\section{PENDAHULUAN}

Kedamaian hidup merupakan idaman dan harapan dari semua orang. Berkaitan dengan itu Adam Smith mengatakan: "Hanya kedamaian, ringannya pajak, dan pelaksanaan peradilan yang dapat diterima yang diperlukan untuk mengangkat negara yang paling melarat menjadi negara paling sejahtera, selebihnya bergantung pada faktor-faktor alami". ${ }^{1}$

Suatu kehidupan yang damai hanya akan tercapai jika di dalam suatu masyarakat tercipta suatu kehidupan yang tertib dan

1 M. Yahya Harahap, Beberapa Tinjauan Mengenai Sistem Peradilan dan Penyelesaian Sengketa, 1997, Bandung : PT. Citra Aditya Bakti, hal. 148. 
Maria Kaban. et al. Pentingnya Penyuluhan Hukum "Penyelesaian Sengketa di Luar Pengabdian...

tenteram. Sebagaimana dikemukakan oleh Soerjono Soekanto. " "Kedamaian dalam pergaulan hidup di satu pihak berarti adanya ketertiban (yang bersifat ekstern antar pribadi atau "interpersonal") dan di lain pihak artinya ada ketentraman (yang bersifat pribadi atau "personal"). Keduanya harus serasi barulah tercapai suatu kedamaian". Sehingga bisa dikatakan bahwa kedamaian akan dapat tercapai apabila tidak ada terjadi persengketaan di masyarakat, jika dilihat lebih jauh untuk masa sekarang ini, upaya yang ditempuh untuk mencegah terjadinya sengketa dapat dikatakan hampir mustahil. Hal itu disebabkan semakin majunya masyarakat, maka akan semakin banyak kemungkinan terjadinya gesekan diantara masyarakat tersebut. Atau dengan kata lain, sengketa atau konflik akan tetap dijumpai dalam kehidupan manusia, khususnya dalam kehidupan bermasyarakat.

Jika dilihat dari kamus Bahasa Indonesia, sengketa dapat diartikan sebagai pertentangan antara orang-orang, kelompokkelompok, atau organisasi-organisasi terhadap satu objek permasalahan. ${ }^{3}$ Senada dengan itu Winardi mengemukakan :

"Pertentangan atau konflik yang terjadi antara individu-individu atau kelompokkelompok yang mempunyai hubungan atau kepentingan yang sama atas suatu objek kepemilikan, yang menimbulkan akibat hukum antara satu dengan yang lain."

Sedangkan menurut Ali Achmad berpendapat bahwa sengketa adalah :

"Pertentangan antara dua pihak atau lebih yang berawal dari persepsi yang berbeda tentang suatu kepentingan atau hak milik yang dapat menimbulkan akibat hukum bagi keduanya"

Sehubungan dengan fakta bahwa sengketa/konflik akan selalu ada di dalam kehidupan manusia, maka manusia itu sendiri tidak bisa menghindari terjadinya sengketa, melainkan harus menghadapi sengketa/konflik tersebut. Secara konvensional, mekanisme yang ditempuh untuk menyelesaikan sengketa/konflik tersebut adalah melalui proses "litigasi"

2 Soerjono Soekanto dan Mustafa Abdullah, Sosiologi Hukum Dalam Masyarakat, 1987, Jakarta : Rajawali Press, hal. 25.

${ }^{3}$ Kamus Besar Bahasa Indonesia yaitu dengan memanfaatkan penyelesaian sengketa melalui jalur pengadilan. Pengadilan mempunyai tempat dan kedudukan yang diandalkan sebagai katup penekan (pressure valve) atas segala bentuk pelanggaran hukum dan diharapkan perannya sebagai "the last resort" yaitu sebagai tempat terakhir untuk mencari kebenaran dan keadilan bagi masyarakat.

Namun pengadilan ini sendiri ternyata memiliki kelemahan-kelemahan yang pada akhirnya membuat penyelesaian sengketa menjadi lebih sulit. Adapun kelemahan tersebut, M. Yahya Harahap ${ }^{4}$ merangkum beberapa kritik terhadap pengadilan yang terjadi pada berbagai negara, yaitu:

\section{Penyelesaian sengketa lambat}

Lambatnya pengadilan dalam menyelesaikan sengketa tergambar seperti yang terjadi di Jepang, rata-rata berlangsung antara 10-15 tahun, di Korea Selatan antara 5-7 tahun, demikian juga di Indonesia, dari tingkat pertama sampai kasasi rata-rata antara 7-12 tahun. Hal ini terjadi sebagai akibat dari tidak adanya pembatasan mengenai jenis perkara yang boleh diajukan kasasi, sehingga semua perkara yang sudah diputus pada tingkat pertama, diajukan kasasi ke Mahkamah Agung. Maka tidak terhindarkan terjadinya penumpukan perkara di MA, yang berakibat semakin lama suatu perkara dapat diselesaikan. Hal tersebut diperparah lagi, dengan prinsip bahwa kekalahan adalah ketidakadilan tanpa mempersoalkan apakah sebuah putusan itu adil dan benar (irrasional).

\section{Biaya berperkara mahal}

Berkaitan dengan lambatnya proses pengadilan, maka akan semakin besar juga biaya yang harus dikeluarkan oleh para pihak yang bersengketa. Biaya yang harus dikeluarkan terdiri dari jasa penasihat hukum (lawyer), transportasi, pendaftaran perkara, succes fee dan biaya lain yang tidak dapat diduga besarannya.Terkadang biaya yang harus dikeluarkan justru lebih besar dari harga sebuah perkara. Anekdot yang

${ }^{4}$ Dirangkum dan dimodifikasi dari $\mathrm{M}$. Yahya Harahap, Loc. cit., 
Maria Kaban. et al. Pentingnya Penyuluhan Hukum "Penyelesaian Sengketa di Luar Pengabdian...

mengatakan "jika kamu kehilangan kambing, maka bersiaplah kehilangan sapi jika berperkara dipengadilan" terasa tepat.

\section{Peradilan pada umumnya tidak responsif}

Tidak responsifnya pengadilan terhadap kepentingan umum, ditandai dengan:

(1) Seringnya pengadilan mengabaikan kepentingan umum dan kebutuhan masyarakat banyak.

(2) Pengadilan sering memberi perlakuan yang tidak adil atau unfair, karena cenderung memberi kesempatan dan keleluasaan kepada lembaga besar dan orang-orang kaya.

(3) Pengadilan kurang tanggap (unresponsive) dalam melayani kepentingan rakyat biasa dan kalangan orang miskin (ordinary citizen).

\section{Kemampuan hakim bersifat generalis}

Hakim adalah sarjana hukum, dan memang itulah persyaratan yang harus dipenuhi seseorang untuk dapat menjadi hakim. Sarjana hukum tentu saja menguasai ilmu hukum, namun tentu juga tidak menguasai ilmu-ilmu lain yang kurang relevansinya dengan ilmu hukum,. seperti ilmu teknik, pertanian, kehutanan, kimia dan sebagainya. Sementara itu perkembangan ilmu pengetahuan dan teknologi telah mendorong terjadinya permasalahan yang multikompleks yang membutuhkan cara penyelesaian berdasarkan keahlian yang profesional. Bagi hakim yang hanya bertitel sarjana hukum, pengetahuannya mengenai suatu sengketa hanya bersifat umum (general). Dalam hal suatu sengketa berkaitan dengan ilmu teknik, sulit diharapkan putusan yang dihasilkan memenuhi unsur objektif dan substansial. Meskipun hakim dapat memanggil saksi ahli, itu belum cukup, karena secara substansial orang yang bukan mendalami ilmu tersebut tetap akan mengalami kesulitan memahaminya.

Melihat kakunya penyelesaian sengketa melalui jalur pengadilan (yang memperlakukan baik kasus yang bersifat ringan dan berat secara sama), maka banyak terdapat kasus yang bersifat ringan dan penyelesaiannya harusnya tidak harus terlalu rumit menjadi panjang dan bertele-tele. Bentuk- bentuk penyelesaian sengketa di luar pengadilan (ADR) pun mulai dicari. Perlu diketahui bahwa istilah ADR ini pertama kali mulai muncul di Amerika Serikat, walaupun secara adat dan budaya sebenarnya esensi dari ADR ini sudah terdapat pada suku-suku bangsa di Indonesia.

Di Indonesia sendiri Peluang Penyelesaian Sengketa Alternatif di Pengadilan ini diatur dalam pasal $130 \mathrm{HIR} /$ 154RBg, di mana pada persidangan pertama Hakim wajib mendamaikan para pihak yang bersengketa. Namun dalam praktek belum didayagunakan secara optimal. Hakimhakim di pengadilan masih bersifat pasif dan upaya menuju ke arah penyelesaian sengketa secara perdamaian diserahkan sepenuhnya kepada inisiatif para pihak yang bersengketa.

Kemudian Mahkamah Agung RI telah mengeluarkan Surat Edaran (SE MARI) No. 1 Tahun 2002 pada tanggal 30 Januari 2002, dan telah disosialisasikan kepada para Hakim Pengadilan Tingkat Pertama. SE MARI No. 1 Tahun 2002 tersebut menginstruksikan kepada semua Hakim (Majelis) yang menyidangkan perkara agar dengan sungguh-sungguh mengusahakan perdamaian dengan menerapkan Pasal 130 HIR / 154 RBg, tidak hanya sekedar formalitas menganjurkan perdamaian.

Perlu juga diketahui bahwa bentuk penyelesaian sengketa alternatif yang kemudian dipilih untuk diterapkan di pengadilan adalah Mediasi, dimana mediator dipilih bisa merupakan hakim mapun nonhakim (mediator yang berkompeten).

SE MARI No.1 Tahun 2002 selanjutnya telah disempurnakan dan ditingkatkan menjadi Peraturan Mahkamah Agung (PERMA) No.2 Tahun 2003 tentang Prosedur Mediasi di Pengadilan, yang ditetapkan oleh Ketua Mahkamah Agung RI, Bagir Manan pada tanggal 11 September 2003.

Dan kemudian PERMA NO. 2 TAHUN 2003 ini kembali mengalami penyempurnaan dengan dikeluarkannya PERMA NO.1 TAHUN 2008 hingga pada tahun 2016 PERMA ini kembali mengalami perubahan menjadi PERMA NO.1 TAHUN 2016. Masyarakat adat Karo yang 
Maria Kaban. et al. Pentingnya Penyuluhan Hukum "Penyelesaian Sengketa di Luar Pengabdian...

berdomisili di Kabupaten Karo merupakan masyarakat hukum yang memiliki sistem hukum adatnya sendiri yang diakui dan dihormati dalam sistem pemerintahan Negara Republik Indonesia. Desa Sarinembah dan Kecamatan Juhar yang berada di wilayah Kabupaten Karo merupakan masyarakat yang menjunjung tinggi hukum adatnya. Penyelesaian sengketa di Desa Sarinembah dan Kecamatan Juhar umumnya dilakukan melalui musyawarah adat. Musyawarah adat dalam bahasa Karo dikenal dengan runggun 5 .

Dengan dikenalnya konsep penyelesaian sengketa alternatif dalam bentuk runggun pada masyarakat adat Karo, seharusnya penyelesaian suatu sengketa adat sudah ada lembaga adat yang menyelesaikannya melalui musyawarah adat. Namun pada kenyataannya masih banyak terdapat gugatan-gugatan sengketa pada Pengadilan Negeri Kabanjahe, padahal ditinjau dari segi pemahaman umum maka seharusnya masyarakat adatlah yang lebih mengetahui bagaimana penyelesaian sengketa adatnya daripada hakim di Pengadilan Negeri. Namun apabila musyawarah adat ini tidak berhasil maka para pihak yang bersengketa akan berusaha untuk mencapai penyelesaian dari sengketa tersebut. Usaha ini akan menghantarkan pihak yang bersengketa pada pengadilan sebagai upaya terakhir (the last resort).

Salah satu sengketa yang sering terjadi di kalangan masyarakat antara lain adalah sengketa tanah. Menurut Maria S.W Sumardjono $^{6}$ secara garis besar, peta permasalahan tanah dapat dikelompokkan menjadi 5 yaitu:

5 Runggun dapat didefenisikan sebagai suatu proses institusional dari musyawarah formal dan pembuatan keputusan melalui mufakat oleh sekelompok orang yang terikat karena kekerabatan sebagai senina, anakberu, dan kalimbubu, yang membentuk kesatuan (sangkep si telu). Herman Slaats and Karen Portier, Traditional Decisioin-Making and Law. 1992. Yogyakarta : Gadjah Mada University Press, hal. 46.

6 Arie S. Hutagalung, Tebaran Pemikiran Seputar Masalah Hukum Tanah, 2005, Jakarta : LPHI, hal. 370.
1. Masalah penggarapan rakyat atas tanah areal kehutanan, perkebunan, proyek perumahan yang ditelantarkan dan lainlain.

2. Masalah yang berkenaan dengan pelanggaran ketentuan tentang Landreform.

3. Ekses-ekses dalam penyediaan tanah untuk keperluan pembangunan.

4. Sengketa perdata berkenaan dengan masalah tanah.

5. Masalah yang berkenaan dengan hak ulayat masyarakat hukum adat.

Meningkatnya jumlah penduduk secara tidak langsung kebutuhan akan tanah semakin meningkat, disamping kebutuhan pembangunan juga untuk pemukiman, sementara tanah yang tersedia jumlahnya terbatas (dalam arti tidak bertambah). Kondisi ini dapat memicu meningkatnya konflik pertanahan seperti penguasaan tanah, penggarapan tanah, dan tumpang tindihnya penggunaan lahan.

Begitu kuatnya hubungan manusia dengan tanah, sehingga diperlukan adanya suatu kekuatan hukum didalamnya. Kekuatan hukum ini akan didapatkan jika sipemilik tanah mendaftarkan tanahnya (perintah dari UU). Dengan terdaftarnya hak-hak atas tanah atau diberikanya hak atas tanah kepada subjek hak. Maka akan tercapailah jaminan kepastian hukum bagi subjek tersebut, artinya subjek hak dijamin untuk menggunakan hak kepemilikan tanah tersebut untuk apa saja asal penggunaan hak tersebut sesuai peruntukannya. Oleh karena itu apabila semua bidang tanah telah terdaftar dan dimanfaatkan oleh pemegang hak, idealnya secara yuridis telah ada jaminan kepastian hak terhadap semua bidang tanah yang telah terdaftar dan dampak positifnya dapat mengurangi permasalahan pertanahan, khususnya yang menyangkut penggunaan dan pemanfaatan serta mempertahankan hak termasuk kebendaan yang melekat padanya.

Sengketa tanah yang timbul di desa pada umumnya adalah sengketa kepemilikan tentang tanah yang disebabkan kurangnya pemahaman masyarakat terhadap pendaftaran tanah. Ditinjau dari jenis konflik pertanahan maka jenis konflik pertanahan yang sering timbul adalah mengenai status 
Maria Kaban. et al. Pentingnya Penyuluhan Hukum "Penyelesaian Sengketa di Luar Pengabdian...

pemilikan tanah. $^{7}$ Salah satu faktor pendorong terjadinya permasalahan ini adalah masyarakat di desa menganggap bukti kepemilikan tanah hanya berdasarkan penguasaan fisik, hal ini yang menyebabkan banyak tanah di desa belum didaftarkan hak atas tanahnya. Oleh karena itu perlu dilakukan sosialisasi mengenai pendaftaran tanah bagi masyarakat desa.

Menurut Pasal 1 PP No. 24 Tahun

1997 tentang Pendaftaran Tanah, pendaftaran tanah adalah rangkaian kegiatan yang dilakukan oleh pemerintah secara terus menerus, berkesinambungan, dan teratur meliputi pengumpulan, pengelolaan, pembukuan dan perjanjian serta pemeliharaan data fisik dan data juridis dalam bentuk peta dan daftar, mengenai bidang-bidang tanah dan satuan rumah susun, termasuk pemberian surat tanda bukti hak bagi bidang-bidang tanah yang sudah ada haknya dan hak milik atas satuan rumah susun serta hak-hak tertentu yang membebaninya. ${ }^{8}$ Dengan dilakukannya pendaftaran tanah maka akan memberikan kepastian hukum dan perlindungan hukum kepada pemegang hak atas sebidang tanah, dan dengan mudah dapat membuktikan dirinya sebagai pemegang hak yang bersangkutan.

\section{PERMASALAHAN}

Sengketa kebanyakan muncul
diakibatkan status
kepemilikan tanah, penguasaan tanah tanpa
alas hak, bahkan masih banyak masyarakat
yang belum memahami fungsi dari
pendaftaran tanah, bahkan tidak mengetahui
bahwa adanya kewajiban untuk mendaftaran
tanah. Dikarenakan ketidaktahuan tersebut
timbul adanya masyarakat yang berpendapat
untuk apa tanah didaftarkan, dan menurut
mereka tanah yang sudah terdaftar itu
bermakna jika tanah itu sudah ada suratnya
(surat apapun namanya dan siapapun yang
menerbitkannya) asalkan terkait
pembuatanya dengan instansi pemerintah,
berarti tanah tersebut sudah terdaftar,
(misalnya ; bukti pembayaran PBB atau

${ }^{7}$ Ibid., hal. 371

${ }^{8}$ Pasal 1 Peraturan Pemerintah No. 24

Tahun 1997 Tentang Pendaftaran Tanah. surat-surat lainya seperti jual beli dibawah tangan, jual beli yang diketahui/disetujui kepala desa/ lurah/ camat dan sebagainya). Hal semacam ini bagi sebagian masyarakat sudah dianggap cukup sebagai petunjuk bahwa tanahnya sudah terdaftar. Pemahaman yang salah ini tidak boleh terus berkembang dan harus diupayakan agar pengertian yang sebenarnya sesuai dengan pemahaman hukum.

Sebagai tindak lanjutnya, kami membentuk Tim Pengabdian Masyarakat sehingga nantinya hambatan-hambatan yang ada di atas tidak lagi dialami, dan penyelesaian masalah melalui mediasi dapat berjalan lebih lancar sehingga penumpukan perkara di pengadilan tidak lagi terjadi serta pemahaman masyarakat mengenai pendaftaran tanah dapat diperluas. Tim Pengabdian Masyarakat akan berusaha semaksimal mungkin sehingga mediasi menjadi opsi utama untuk menyelesaikan sengketa di masyarakat serta menambah pengetahuan masyarakat mengenai pendaftaran tanah.

Sehubungan dengan hal itu, dibuatlah rumusan masalah sebagai berikut :

1. Apakah upaya terbaik yang harus dilakukan oleh tim pengabdian masyarakat serta manfaat yang akan diperoleh mitra mitra (masyarakat Desa Sarinembah dan Kecamatan Juhar, Kabupaten Karo) dalam hal menjadikan mediasi sebagai opsi utama dalam penyelesaian sengketa, khususnya di Desa Sarinembah dan Kecamatan Juhar, Kabupaten Karo?

2. Apakah upaya terbaik yang harus dilakukan oleh tim pengabdian masyarakat serta manfaat yang akan diperoleh mitra (masyarakat Desa Sarinembah dan Kecamatan Juhar, Kabupaten Karo) dalam hal menanamkan pentingnya pendaftaran tanah bagi warga di Desa Sarinembah dan Kecamatan Juhar, Kabupaten Karo?

3. Manfaat apa yang dapat diperoleh oleh pemerintah dalam hal ini pihak Kabupaten Karo dengan diadakannya pengabdian oleh pihak akademisi? 
Maria Kaban. et al. Pentingnya Penyuluhan Hukum "Penyelesaian Sengketa di Luar Pengabdian...

\section{METODE PELAKSANAAN}

Kegiatan yang dilakukan dalam pengabdian masyarakat ini adalah dalam bentuk:

1. Ceramah umum kepada kelompok sasaran antara yang strategis antara lain Camat, Aparatur Camat, Kepala Kelurahan dan Aparatur Kelurahan, Kepala Desa, tokoh-tokoh masyarakat, tokoh agama, tokoh pemuda dan karang taruna serta anggota masyarakat dengan berbagai profesi yang ada di kelurahan yang menjadi mitra.

2. Tanya jawab langsung (diskusi) antara penceramah dengan kelompok sasaran.

3. Secara keseluruhan melihat perkembangan pelaksanaan mediasi dan pelaksanaan pendaftaran tanah di desa dan kecamatan yang menjadi mitra

\section{HASIL PENGABDIAN}

Kegiatan pengabdian di Desa Sarinembah dilakukan di ruangan kantor Kepala Desa Sarinembah pada hari Rabu, 26 Oktober 2016 di Desa Sarinembah, Kecamatan Munte, Kabupaten Karo, Provinsi Sumatera Utara. Desa ini merupakan salah satu dari 2 (dua) desa di Kecamatan Munte yang masih terdapat hak atas tanah ulayatnya dan hingga saat ini rawan terjadi sengketa atas tanah adat dikarenakan banyaknya tanah yang belum didaftarkan oleh pemiliknya. Untuk itu penyuluhan ini bertujuan untuk membantu masyarakat dalam menyelesaikan masalahnya melalui penyelesaian sengketa di luar pengadilan dan memberikan pemahaman mengenai pentingnya pendaftaran tanah untuk memperkuat kepastian hak atas tanah.

Kegiatan ini diawali dengan tahapan persiapan yaitu pengurusan administrasi termasuk penentuan jadwal pengabdian masyarakat. Kegiatan ini hanya dilakukan satu periode saja, mengingat waktu masyarakat yang tidak banyak (warga tentunya memiliki kesibukan masingmasing).

Acara dimulai pada jam 13.00 WIB dengan kata sambutan dari Bapak Kepala Desa Sarinembah setelah sebelumnya diadakan acara makan bersama dengan para peserta dan perangkat Desa Sarinembah diikuti dengan perkenalan dari tim pengabdian masyarakat Fakultas Hukum Universitas Sumatera Utara kepada para peserta. Kemudian dilakukan pembagian buku saku mengenai penyelsaian sengketa kepada para peserta dan dilanjutkan dengan presentasi dari para pemakalah yang dipimpin oleh moderator. Pada saat kegiatan ini dilakukan terlihat seluruh peserta antusias mengikutinya, hal ini dapat dilihat dari jumlah kehadiran dan banyaknya pertanyaan yang diajukan oleh para peserta dan juga menimbulkan perdebatan antara peserta yang ditengahi oleh pemakalah.

Pengabdian masyarakat ini ditutup dengan makan siang bersama para peserta dan camat Juhar yang telah disediakan oleh tim pengabdian masyarakat Fakultas Hukum Universitas Sumatera Utara. Kemudian secara resmi ditutup oleh Camat Juhar dan foto bersama dengan para peserta dan camat Juhar di akhir acara.

Kegiatan pengabdian berikutnya dilaksanakan di Aula Kecamatan Juhar pada hari Kamis, 27 Oktober 2016 di Kecamatan Juhar, Kabupaten Karo, Provinsi Sumatera Utara. Menurut Camat Juhar, Kecamatan Juhar merupakan tolak ukur peradatan Karo sehingga Kecamatan Juhar merupakan desa percontohan dalam peradatan Karo di Kabupaten Karo. Hal ini terbukti dari 25 (dua puluh lima) desa yang terdapat di Juhar, 12 (dua belas) desa masih memiliki tanah ulayat yang diakui oleh masyarakatnya dimana beberapa tanah ulayat yang masih bertahan berada dalam keadaan sengketa. Untuk itu pengabdian masyarakat ini bertujuan untuk menindaklanjuti hasil penelitian terdahulu sehingga sengketa tanah ulayat yang berada di masyarakat tidak sampai masuk ke pengadilan karena telah dapat diselesaikan secara damai.

Hal ini diawali dengan tahapan persiapan yaitu pengurusan administrasi termasuk penetuan jadwal pengabdian masyarakat. Kegiatan ini hanya dilakukan satu periode saja, mengingat waktu masyarakat yang tidak banyak (warga tentunya memiliki kesibukan masingmasing).

Acara dimulai pada pukul 10.00 WIB yang dibuka dengan kata sambutan oleh Camat Juhar, diikuti Sekretaris Camat Juhar, dan perkenalan dari tim pengabdian 
Maria Kaban. et al. Pentingnya Penyuluhan Hukum "Penyelesaian Sengketa di Luar Pengabdian...

masyarakat Fakultas Hukum Universitas Sumatera Utara kepada para peserta kemudian pemberian buku saku kepada para peserta agar dapat lebih lanjut dalam mempelajari tentang penyelesaian sengketa. Dilanjutkan dengan presentasi dari para pemakalah yang dipimpin oleh moderator. Pada saat kegiatan ini dilakukan terlihat seluruh peserta antusias mengikuti, hal ini dapat dilihat dari jumlah kehadiran banyaknya pertanyaan yang diajukan oleh para peserta, namun dikarenakan waktu terbatas tidak memungkinkan untuk menjawab semua pertanyaan.

Pengabdian masyarakat ini ditutup dengan makan siang bersama para peserta dan camat Juhar yang telah disediakan oleh tim pengabdian masyarakat Fakultas Hukum Universitas Sumatera Utara. Kemudian secara resmi ditutup oleh Camat Juhar dan foto bersama dengan para peserta dan camat Juhar di akhir acara.

Di akhir pelatihan dapat disimpulkan bahwa sebenarnya melalui penyuluhan semacam ini masyarakat akan lebih mudah untuk menerima cara-cara penyelesaian sengketa secara damai karena masyarakat langsung diajak berdiskusi dan dapat menanyakan secara langsung hal-hal yang dianggap kurang jelas.

Memperhatikan semua tujuan

kegiatan pengabdian masyarakat ini, yaitu untuk meningkatkan pemahaman warga masyarakat dan menyebarluaskan informasi mengenai berbagai segi penyelesaian sengketa di luar pengadilan dan pendaftaran tanah terutama dari aspek hukumnya, sekaligus untuk memberdayakan masyarakat untuk ikut secara aktif dalam rangka mensosialisasikan manfaat pendaftaran tanah dan penyelesaian sengketa di luar pengadilan. Hal ini dapat dibuktikan dari tanggapan para peserta yang sangat antusias dalam mengajukan pertanyaan-pertanyaan dalam sesi tanya jawab terhadap materi pengabdian masyarakat yang kurang dapat dipahami serta membawa permasalahanpermasalahan yang terjadi di lingkungannya untuk dapat dicarikan jalan keluar penyelesaiannya.

\section{KESIMPULAN DAN SARAN}

\section{Kesimpulan}

1. Masyarakat menjadi lebih mengerti mengenai alternatif lain dalam penyelesaian sengketa yaitu melalui jalur mediasi yang ternyata lebih menghemat waktu serta melakukan pendaftaran tanah untuk mejamin kepastian hukum kepemilikan atas tanah.

2. Para pemuka masyarakat, agama maupun perangkat Desa Sarinembah dan Kecamatan Juhar menyatakan akan berusaha untuk mengarahkan sengketa perdata yang terjadi di dalam masyarakat Desa Sarinembah dan Kecamatan Juhar penyelesaiannya dilakukan melalui jalur mediasi serta meningkatkan minat masyarakat untuk melaksanakan pendaftaran tanah.

3. Pengabdian masyarakat seperti ini juga turut membantu sosialisasi pemerintah dalam bidang hukum.

\section{Saran}

Setelah dilaksanakannya pengabdian masyarakat ini, diharapkan masyarakat Desa Sarinembah dan Kecamatan Juhar dapat melihat bahwa dalam menyelesaikan sengketa terutama sengketa perdata, tidak harus melalui jalur pengadilan yang cenderung menghabiskan banyak biaya daan waktu serta menyebabkan penumpukan kasus di pengadilan, namu tersedia jalur lain yang lebih hemat biaya dan waktu yaitu melalui penyelesaian sengketa alternatif dan dalam hal pendaftaran tanah agar masyarakat dapat melaksanakan pendaftaran tanahnya untuk menjamin kepastian hukum serta menghindarkan terjadinya sengketa.

\section{DAFTAR PUSTAKA}

\section{Buku/Makalah :}

Harahap, M. Yahya. Beberapa Tinjauan Mengenai Sistem Peradilan dan Penyelesaian Sengketa. 1997. Bandung: PT. Citra Aditya Bakti.

Hutagalung, Arie S., 2005. Tebaran Pemikiran Seputar Masalah Hukum Tanah. Jakarta : LPHI. 
Maria Kaban. et al. Pentingnya Penyuluhan Hukum "Penyelesaian Sengketa di Luar Pengabdian...

Slaats, Herman and Portier, Karen. 1992. Traditional Decisioin-Making and Law. Yogyakarta : Gadjah Mada University Press.

Soekanto, Soerjono dan Abdullah, Mustafa.Sosiologi Hukum Dalam Masyarakat, 1987. Jakarta : Rajawali Press.

Sumardjono, Maria S. W. 2005. Kebijakan Pertanahan, Antara Regulasi dan Implementasi. Jakarta : Kompas.

Kamus Besar Bahasa Indonesia.

Undang-Undang dan Peraturan
Pemerintah
Pasal 130 HIR / 154 RBg

Peraturan Pemerintah No. 24 Tahun 1997

Tentang Pendaftaran Tanah

Undang-Undang No. 51/PRP/1960 tentang Larangan Pemakaian Tanah Tanpa Ijin

Undang-Undang Nomor 25 Tahun 1997 tentang Ketenagakerjaan

Surat Edaran (SE MARI) No. 1 Tahun 2002

PERMARI NO.2 TAHUN 2003 jo PERMARI NO.1 TAHUN 2008 jo PERMARI NO. 1 Tahun 2016 tentang Prosedur Mediasi di Pengadilan

Undang-Undang No. 30 Tahun 1999 tentang Arbitrase dan Alternatif Penyelesaian Sengketa 